\title{
Beyond Silence: Giving Voice To Kure Mothers of Japanese- Australian Children
}

\author{
Kathleen Cusack \\ University of Wollongong
}

\begin{abstract}
Within the complex process of historical production, silence is created, imposed and fostered. Encountering the existence of a cast of hitherto silent actors within history, therefore, is wholly unsurprising. This article draws focus to a cohort of Japanese women who have been excluded from conventional interpretations. Indeed, the experiences of the Kure women who bore children fathered by Australian servicemen during the occupation have been consistently marginalised to the periphery of existing scholarship on this period.

By applying a gendered perspective to the analysis of a selection of previously unexamined newspaper articles, this article will demonstrate that a meaningful history can be written for those excluded from primary or secondary discourse. This article will show that these women do possess a historically significant past through revealing that they were active participants in the post-war period who influenced the conduct of the military operation. Most importantly, this article will confront some of the imposed barriers of silence through analysing certain aspects of the women's experiences within limited available material. This examination will illuminate prevalent local attitudes towards women involved in relationships with foreign servicemen and the predominance of the socially and culturally derived construct of the feminine role.
\end{abstract}

\section{Keywords}

Gender, Occupation, Fraternisation and Historical Silence

\section{Introduction}

Between 1946 and 1954, fifty-one children fathered by Australian military personnel were born in Kure, Japan. ${ }^{1}$ Such a figure appears wholly unremarkable particularly given

1 National Archives of Australia (herein referred to as NAA); A1838; 3103/10/12/1 PART 1, 'Social Study of Children of Mixed Ethnic Origin in Kure City, 
.n.m.n. of

the rapid population growth of the post-war period but these children were born during the occupation of Japan. More intriguingly, the children were the product of sexual relations between Japanese women and Australian servicemen stationed in the region as part of the British Commonwealth Occupation Force and the British Commonwealth Forces, Korea (herein referred to as BCOF and BCFK). ${ }^{2}$ This article will focus upon the mothers of the children, not least because they were encumbered with the sole responsibility of their offspring following the withdrawal of the Australian units. Furthermore, their experiences cast light upon previously unexamined factors concerning the impact of the occupation upon Kure citizens as, for example, predominant social attitudes towards those involved in relationships with personnel.

The occupation of Japan commenced immediately upon the cessation of hostilities in August 1945 and concluded upon the ratification of the peace treaty in April 1952. The Australian military presence in Japan, however, extended from February 1946 through to November 1956, as a consequence of the outbreak of the Korean War. ${ }^{3}$ The primary purpose of the occupation was to transform the defeated Japanese military dictatorship into a peaceful democracy through the means of an extensive demilitarisation and democratisation program. America alone controlled the formulation and administration of basic policy for the duration of the occupation but the Australian contingent exercised an influential role within the multi-national British Commonwealth Occupation Force. ${ }^{4}$ It is this overarching environment of military occupation that framed the relationships formed between personnel and Japanese women. ${ }^{5}$

At its height, the BCOF numbered 40,000 servicemen and women, of whom, 11,500 were Australian. The Australian division was primarily stationed in Kure, which had served as a principal naval base for the Imperial Japanese Navy prior to the destructive air raids in the latter stages of the war. ${ }^{6}$ The occupation of Kure was, in fact, largely administered by the BCOF, a feature that distinguishes this area from other regions of Japan that were occupied solely by the American forces. ${ }^{7}$ It is the predominance of the Australian contingent within this region that can partially account for this concentration of children with Australian paternity in Kure. ${ }^{8}$

Hiroshima-ken, Japan,' 15 September 1958.

2 NAA; A463 (A463/63) 1963/2728, 'Illegitimate Children of Australian Servicemen in Japan, 27 January 1958.

Tamura, Michi's Memories, p. 3.

Wood, The Forgotten Force, p. 51.

Carter, Between War and Peace, p. 2.

Tamura, op. cit., p. 2.

Chida, (ed.), Kure No Ayumi II, p. 315.

This was an outcome of military occupation that was certainly not unique to Japan. As Biddiscombe explains in 'Dangerous Liasons', more than 37,000 children were born as a result of sexual relations between American personnel and local women during the post-World War II occupation of Germany and Austria. The majority of these children became wards of German and Austrian welfare services and were never adopted. 
Addressing such aspects of the occupation contextualise the discussion of women who gave birth to children fathered by Australian servicemen in this period. More importantly, foregrounding the role of the occupiers draws attention to the fact that it has been the victors who have captured attention in historical discourse. As Dower articulates, 'winning, more than losing, has defined the moment.'

Recently, the military occupation of Japan as an experience for the occupied has provided the focus for much scholarly examination. The parameters of historical significance within this literature have not, however, been extended to include the women who bore children fathered by Australian personnel. Unfortunately, it is not only within past and existing scholarship that the experiences of these women have been marginalised to the periphery. There is also a distinct absence of accessible empirical source material that directly addresses this cohort of women.

The limited acknowledgement of these women can be partly attributed to the function of silence within historical production but silence is neither a neutral nor natural occurrence within this discipline. It can hence be argued that any exclusion of these women is an indication of systematic patriarchal concerns rather than the historical insignificance of their experiences. This article aims to overcome some of the imposed barriers of silence by analysing the experiences of the women within limited available material. Such analysis will help unearth prevalent local attitudes towards women involved in relationships with foreign servicemen and the predominance of the socially and culturally derived construct of the feminine role in this period. This article adopts a gendered perspective based on the proposition that,

Our historical silence is then merely an effect. It is the beginning not the end of our history. ${ }^{10}$

\section{Silence and the Production of History}

The discipline of history is established upon the central premise that there is a clear delineation between the past and history itself. The past is conceived to include all that has occurred regardless of whether it was recorded, whereas history, in contrast, is defined as what historians represent the past to have been. ${ }^{11}$ What lies between these two constructs are agents of the past that have been silenced, omitted and marginalised by historical discourse. ${ }^{12}$ The existence of a cast of hitherto silent actors within history is

\footnotetext{
Dower, Embracing Defeat, p. 24.

Allen, 'Evidence and Silence,' in Pateman and Pateman (eds.), Feminist Challenges: Social and Political Theory, p. 189.

Wilkinson, 'A Choice of Fictions: Historians, Memory, and Evidence', p. 80.

Trouillet, Silencing The Past, p. 26-27.
} 
.n.m.n. of

not wholly unsurprising, as the very act of remembering, enacted in the recording of history, necessarily entails a coalescent act of forgetting. ${ }^{13}$ As Finney articulates,

Historical texts are structured representations that...both silence as well as reveal, encode and decode, assign voice and authority to some and deny it to others. ${ }^{14}$

Whilst the list of those excluded from conventional interpretations is extensive, the silence imposed upon Japanese mothers of children born by Australian servicemen reveals the encoding and assignation of both authoritative and submerged voices.

It has only been relatively recent that women have been positioned as distinct subjects of historical inquiry. As Lake argues,

History was, as often as not, the record of men's public work of nation building - through parliaments, politics, commerce and war. ${ }^{15}$

The privileging of public, political activities and the omitting or trivialising of private, subjective experience within the discipline has, in the past, resulted in rendering women historically invisible. Primarily concentrated on the analysis of women and the development of feminist identities in history, the central premise of gender history is to address this absence through reformulating the understanding of the past in terms of the socially and culturally derived constructions of masculinity and femininity. ${ }^{16}$ In spite of the implications, however, gender is not a synonym for women nor is gender history able to be equated merely with history of the biological female sex. ${ }^{17}$ Rather, it is a means through which the intersection between power, control and domination exercised within the constructs of masculinity and femininity can be identified. As will be examined in the following section, relationships between Japanese women and Australian military personnel were conducted within a framework of a distinct and gendered disparity in power.

The rich and varied experiences of the women who bore children to Australian personnel have been consistently relegated to the periphery of the existing literature. This absence can be attributed to four primary factors. First, historical works concerned solely with the paramount role of America in reforming occupied Japan have dominated both Western and Japanese scholarship since the conclusion of the occupation. ${ }^{18}$ The

\footnotetext{
Roberts, 'History and Memory', p. 515.

Finney, 'Still 'Marking Time'?', p. 298.

Lake, 'Nationalist Historiography, Feminist Scholarship, and the Promise and Problems of New Transnational Histories', p. 180.

Black and MacRaild, Studying History, p. 147.

Green and Troup, Houses of History, p. 256-257.

See for example: Baerweld, The Purge of Japanese Leaders under the Occupation; Reischauer, Japan: Tradition and Transformation; Passin, 'The Occupation
} 
conservative approach of these policy examinations privilege the masculine public domain and neglect the investigation of subjects that cannot be encompassed within these narrow parameters. Second, there exists a failure within these predominantly American works to address the occupation of Japan in terms of 'its own times and values. ${ }^{\text {'19 }}$ Both Moore and Dower attribute this to a predilection to view the period as an 'American show' rather than a significant moment in Japanese history. Additionally, there is an inclination amongst some Western scholars to concentrate solely upon examining the occupation from the perspective of the victors. ${ }^{20}$ It is a propensity that can be partly assigned to limitations presented by language. Finally, the interaction of personnel with Japanese women is most often described only within the context of either prostitution or marriage. ${ }^{21}$ This approach excludes discussion of the women addressed in this article who cannot be categorised within these constraints.

The marginalisation of women who bore children to Australian servicemen within existing literature presents a predicament that is best articulated by Passerini,

...very often, especially researching those who lost and were repressed, we have the experience of finding people, ideas, books, which seem to have completely disappeared, which have vanished leaving only scattered and tantalising trace, in spite of all our efforts. ${ }^{22}$

According to Elton, the perceived absence of material compromises the credibility of an historical examination and entirely undermines the necessity for conducting such an investigation at all. Elton proposes that such a quandary can be wholly dismissed with the apparently irrefutable statement, 'it is as they had never been.' ${ }^{23}$ As Allen argues, however, examinations of women and their experiences cannot be satisfied by such an arrogant conclusion. ${ }^{24}$ It is inexcusable to presume that women do not have a historically significant past merely because they have been silenced in primary or secondary discourse.

Expanding upon research led by such scholars as Chida and Tamura, this article represents an attempt to redress aspects of this silence. In addition to historical fiction, personal memoirs and oral interviews, archival documents have been sourced to elucidate certain aspects of the experience for Kure mothers of Japanese-Australian children. These women receive brief mention within items concerning the welfare of

\footnotetext{
Some Reflections', p. 107-129.

9 Carter, Between War and Peace, p. 7.

See for example: Davies, The Occupation of Japa; Torney, 'Renegades to Their Country', p. 89-110.

See for example: Carter, Between War and Peace; Wood, The Forgotten Force.

Passerini, 'Memories Between Silence and Oblivion,' in Hodgkin and Radstone (eds.), Contested Pasts: The Politics of Memory, p. 250.

Elton, 'The Practice of History' in Allen, 'Evidence and Silence', in Pateman and Pateman (eds.), Feminist Challenges: Social and Political Theory, p. 176.

Allen, 'Evidence and Silence,' in Pateman and Pateman (eds.), op. cit., p. 176.
} 
their children and such documents will be drawn upon to explore how their experiences were framed by the construct of motherhood.

It is a collection of local newspapers archived in the Kure History Office, however, which will form the principal focus of analysis in this examination. The articles published were written for the greater Japanese community and as such, address topical social issues of the period including the fraternisation of women with foreign servicemen. ${ }^{25}$ In view of the absence of such material in any other archival institution in Japan, these newspapers, to the best of my knowledge, are also the only accessible records that include details of this particular cohort of women. For this investigation, I translated and examined approximately thirty newspaper articles from the Chügoku Nippo and the Chügoku Shinbun. The articles are drawn from 1946 through to 1956 but even in spite of this breadth, there is only one article that directly addresses the women who bore children to the Australian personnel. ${ }^{26}$ There are a significant number, however, that refer indirectly to the women, particularly those concerning their children. As the preceding analysis will demonstrate, moreover, those who are silent speak eloquently about the meanings and uses of power. ${ }^{27}$

\section{A Historically Significant Past}

The Ministry of Welfare in Japan estimated that there were approximately 3,490 'mixed blood' children born in the occupation period, of which 104 had Australian fathers. ${ }^{28}$ According to an investigation conducted by the International Social Service of Japan in 1958, there were sixty-seven so-called 'mixed-blood' children born in the Kure area between 1946 and 1954. Of these children, Australian personnel of the BCOF and the BCFK fathered fifty-one. ${ }^{29}$

Associations between the parents of these Japanese-Australian children developed within the framework of a distinct disparity in power. As Dower explains, inequality between the victors and the vanquished is inherent in a military occupation. ${ }^{30}$ The responsibilities and obligations assumed by the BCOF confirmed this division but the BCOF authorities sought to foster this disparity even further. ${ }^{31}$ Carter attributes the desire to preserve this hierarchical separation to the perceived importance of projecting

\footnotetext{
Chida, 'Japanese Research on the Occupation of Post-War Japan by British and Commonwealth Forces'.

See for example: 'Hopeless Mother Committed Theft For Her Two Children; Aware konketsuji no hahaoya 2ji o kakaete nusumi,' Chügoku Nippo, 6 May

952 (For the purpose of this article, both the English translations and römaji titles from the Australia-Japan Research Project database have been used).

Scott, Gender and the Politics of History, p. 24.

NAA; A463 (A463/63) 1963/2728, 'Department of External Affairs: Inward Savingram', 29 January 1960.

NAA; A1838 3103/10/12/1 PART 1, 'Social Study of Children of Mixed Ethnic Origin in Kure City, Hiroshima-ken, Japan,' 15 September 1958.

Dower, Embracing Defeat, p. 207.

Torney, 'Renegades to Their Country', War and Society, 25, 1, May, 2006, p. 90.
} 
a disciplined and prestigious image of the force within Japan. ${ }^{32}$ Such cultivation also served as a means of confronting the subordinate status the BCOF had been assigned within the American occupation. ${ }^{33}$

The attempts of the BCOF authorities to encourage this disparity in power can be partly attributed to the women who form the subject of inquiry in this article. As the BCOF authorities were aware, the majority of personnel were drawn to the particular appeal of the primarily young women. ${ }^{34}$ As Keith Boothroyd, a corporal with the $67^{\text {th }}$ Infantry Battalion, suggests, such attraction was premised upon the notion that the women bore little or no responsibility for the destruction perpetuated by the war, 'You see the Japanese civil population were entirely different to their army'.35 Attributed to the association of the oriental with the feminine erotic, young women were also viewed to be submissive, graceful and possessing few inhibitions regarding nudity. ${ }^{36}$ It was an appeal that was considered to be entirely distinct from that of Australian women and best encapsulated in this excerpt,

The small-boned delicacy and fragility of the more attractive Japanese girls was very appealing to the womanless troops, used to Australian girls who demanded co-partnership, they found the polite submissiveness, the desire to please of the Japanese musume intoxicating. ${ }^{37}$

The attraction the women posed for the occupying troops and the possibilities this created for fraternisation had a critical effect upon the division the BCOF authorities hoped to enforce between the victors and the vanquished. Moreover, it awarded this cohort of women a limited agency distinct from the disenfranchised status that encumbered the remaining occupied population.

Most evident of the extent to which the BCOF authorities viewed the women to be a threat to the objectives of the military operation was the introduction of a strict nonfraternisation policy early in the occupation. ${ }^{38}$ Issued in the form of a personal instruction from former Commander-In-Chief Lieutenant General Northcott, the policy advised,

Every member of the BCOF must bear in mind that he is present in Japan in dual capacity. He is not only a sailor, a soldier or an airman. He is also a representative of the British Commonwealth of Nations and all that

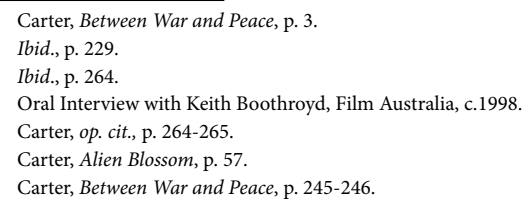


.

stands for in the world... Your relations with this defeated enemy must be guided largely by your own judgement and your sense of discipline... You must be formal and correct... Your unofficial dealings with the Japanese must be kept to a minimum. ${ }^{39}$

According to Wood, the instruction was largely motivated by the 'deep suffering and loss' sustained throughout the Commonwealth and a desire to protect the health and well being of the troops. ${ }^{40}$ Furthermore, as Carter explains, it aimed to impede expressions of hostility or violence against the Japanese community, as it was widely viewed that this would affect the prestige of the force. ${ }^{41}$ The emphasis upon minimising informal contact with citizens and encouraging troops to adopt a formal attitude in situations where interaction was unavoidable, however, is clearly designed to prevent the development of intimate relations between servicemen and local women.

The desire to deter further interaction can be primarily attributed to the view promulgated by the BCOF authorities that the women were an unwholesome, immoral attraction. ${ }^{42}$ It was this attitude that resulted in the enforcement of arbitrary venereal disease examinations amongst females in the region. ${ }^{43}$ Whilst the screenings were understandably instituted amongst prostitutes, the examinations were also forced upon any female observed in the company of servicemen regardless of their position. ${ }^{44}$ This is exemplified in this excerpt from Alien Blossom,

The Jap police have arrested Cherry, a Jap kid who works in our R.A.P. at Hiro. Just because we were walking along the street together. There was nothing wrong in it! I take it as an insult to both of us. Because she was seen with an Australian soldier she's a tramp and a prostitute $!^{45}$

Such visible condemnation of the women as receptacles of venereal disease served to class all as particularly dishonourable and distinguish them further from civilised standards assumed to be embodied in the Western woman. ${ }^{46}$

The majority of personnel viewed the non-fraternisation policy as unnecessary, unreasonable and inconsistent with the aims of the occupation, particularly those regarding the ambiguous process of democratisation. ${ }^{47}$ As Coffman contends,

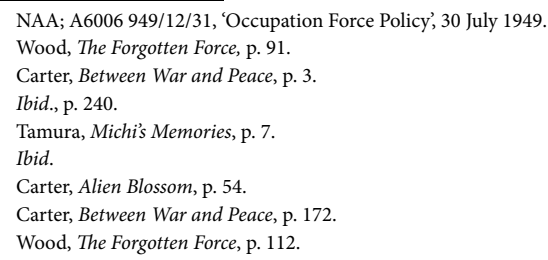


...the senior officers responsible for it were shortsighted and didn't realise the good work from the point of democracies that could be done by associating with the people. ${ }^{48}$

The servicemen, who desired to form relations with Japanese women, of course, particularly resented the policy. ${ }^{49}$ Indeed, as Hungerford explains, Australian servicemen were keen to initiate contact with young women in the area immediately upon disembarking,

Leave hadn't been granted but as soon as the men had filled one part of their anatomy, they began thinking about emptying-or at least tappinganother. Before long little groups were flitting off into the uncharted ruins of Kure in search of which, generally they had been deprived of for upward of a couple of years. ${ }^{50}$

This excerpt also implies that the women were viewed as vehicles of sexual release for personnel, which exemplifies the limitations of the agency these women were attributed within the overarching military environment.

The non-fraternisation instruction was not only ineffectual in minimising contact between personnel and local women but it served to drive fraternisation underground and prompt servicemen to seek much more easily available options such as prostitutes. ${ }^{51}$ The financial advantage of the foreign personnel coupled with the economic hardship of the post-war period had stimulated the prostitution industry and it was within this context that relationships between personnel and Kure women first emerged. ${ }^{52}$ The voracity with which the personnel engaged in casual, sexual encounters early in the occupation is best expressed through the statistical figures concerning venereal disease. From February 1946 to December 1947, 7,937 cases of venereal disease were diagnosed amongst the Australian units. ${ }^{53}$ Whilst the figures are not entirely reliable as the cases reported include relapsed infections, the incidence of the disease is still extraordinarily high given that only 12,000 servicemen were stationed in Japan at the peak of Australia's contribution. ${ }^{54}$

Fraternisation between Australian servicemen and Kure women was not, however, limited to such liaisons. ${ }^{55}$ The employment of ten percent of the population

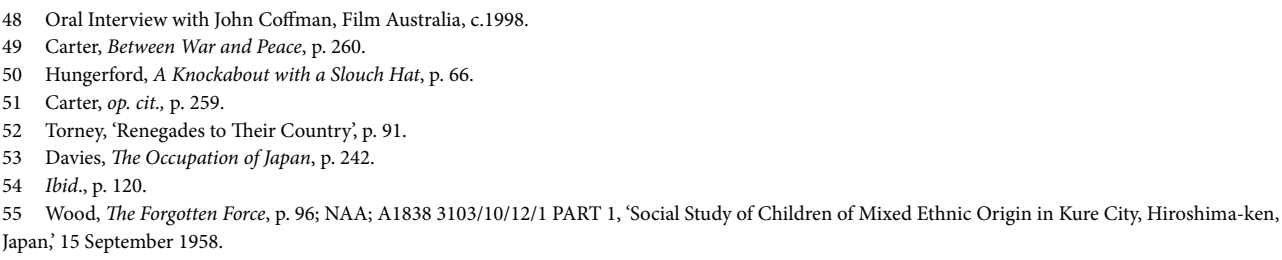


.n.m.n. of

within the military camps necessarily entailed close and frequent contact, which served to aid the development of amicable relations between the occupiers and the occupied. Although it was in a much lesser capacity, such attitudes were also fostered through the development of the mutually beneficial black market system. ${ }^{56}$ It was the gradual progression from the 'stern rigidity of a military occupation to the friendly guidance of a protective force', however, that was most instrumental in encouraging this subsequent divergence in attitudes amongst both parties. ${ }^{57}$ As Grant, a member of the Australian contingent, articulates,

...we just simply found you couldn't live among a people and maintain an unbending degree of hatred or even dislike. ${ }^{58}$

According to Tamura, it wasinevitable that interactions within common workplace and social environments would eventually develop into sexual relationships. ${ }^{59}$ Passmore, a nurse employed within the $130^{\text {th }}$ Australian General Hospital, enigmatically alludes to the close associations that often emerged between officers and their house girl,

...we women, we were allotted a house girl between two who looked after us...But so did the men and they used to get massaged and that sort of thing...They had to make their own amusements and do their own thing, and that's where problems came about. ${ }^{60}$

The emphasis upon the importance of such factors, however, masks the agency the women exerted in their decisions to pursue relationships with personnel. The women employed within the prostitution industry, for example, viewed the establishment of the occupying force in Kure as a means to combat the economic hardship of the post-war period. This sentiment is exemplified in the following description of the arrival of the BCOF in the port, where prostitutes greeted the incoming ships, 'offering their bodies in exchange for practically anything they could smoke, eat or barter. ${ }^{61}$ This mutually beneficial system had been adopted during the earlier American occupation in the area and was willingly continued during the BCOF administration by the vast number of prostitutes residing in Kure.

There were numerous other women, however, who pursued relationships with personnel for reasons that were entirely distinct from this desire for material necessities. Young women, in particular, were attracted to the Western ideals espoused by the

\footnotetext{
Torney, op. cit., p. 91.

NAA; A6006 1949/12/31, 'Occupation Force Policy', 30 July 1949.

Oral Interview with Mac Grant, Film Australia, c.1998.

Tamura, 'An Ordinary Life?,' Meanjin, 61, 1, March, 2002.

Oral Interview with Phyllis Passmore, Film Australia, c.1998.

Elliot, Occupational Hazards, p. 19.
} 
servicemen. Accustomed to more restrictive male dominance, this cohort of women embraced the notion that the female partner could be regarded equally in a relationship. This is best expressed by the character, Cherry, in Alien Blossom,

It had been customary all her life to see Japanese women walking politely in the shadows of their husbands, though, this was one of the small humilities which new, fresh winds were beginning to sweep out of Japan. ${ }^{62}$

Moreover, many women viewed relationships with Australian servicemen as a means of confronting the unappealing prospect of not merely coping with post-war hardships without a marriage partner but of never marrying at all. This was a very real outlook for women between the ages of twenty and twenty-nine, who had come to outnumber men by more than one million in 1947 through circumstance of war. ${ }^{63}$ This fear of remaining unmarried and childless is articulated well in this extract from Michis Memories,

I was already getting old and there was no prospect of marrying a Japanese man and having children with him. ${ }^{64}$

This is not to imply, however, that all women were involved in such relationships for their own economic or social benefit. Many women developed genuine affection and respect for their partners. This was exhibited in the increasing number of couples who lived together as the occupation developed,

Some men had "shacked up" permanently with girls from the dance halls and teahouses, reporting for duty, but hardly making a pretence of living in the barracks. ${ }^{65}$

Regardless of the motivation, the majority of the women involved exerted a degree of agency in the decision to pursue such close associations with the personnel. Furthermore, the relationships that emerged were a 'phenomenal cultural event' as they defied the very inequalities that had been imposed in this occupation. ${ }^{66}$

By the conclusion of 1946, approximately three children of Australian paternity had been born and in the following year, a further thirteen were born. ${ }^{67}$ Passmore reflects upon the immediacy with which such children were produced,

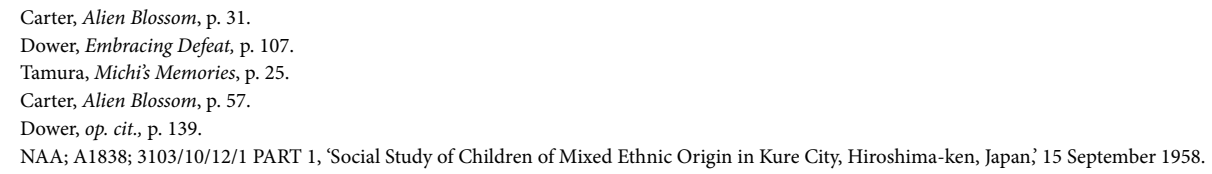


.

...You see, if you saw a brown headed Japanese, you'd think, "Hello, the Yanks or the Aussie's have been around"...That was going on before we left, before I left in ' $47 .{ }^{68}$

The birth of these children in this very early period of the occupation coupled with the keen involvement of the personnel in the prostitution industry indicates that many of the mothers may certainly have been prostitutes.

It does not transpire, however, that the women who gave birth to children fathered by Australian personnel in subsequent years were also involved in this industry. Indeed, many of the women were married when they gave birth ${ }^{69}$ As the marriages had been contracted through a Shinto or Buddhist ceremony, however, they were not viewed as legally binding by the BCOF authorities. Despite numerous couples expressing a desire to formalise their commitment through marriage, the Australian government actively discouraged this action upon principles adopted by the Ministry of Immigration that forbade the entry of wives 'of Asiatic origin to Australia. ${ }^{70}$ Such opposition was not limited to that of the Australian government; the women were also subject to criticism and disapproval from their families, colleagues and associates. This sentiment is exemplified in this excerpt from Michis Memories,

Yet, they opposed it strongly when I said that I wanted to marry Gus. At the beginning, they talked as if I should be disowned. ${ }^{71}$

Prior to the removal of the prohibition upon marriage in 1952, these couples were confronted with the prospect that the servicemen were unable to remain in Japan following the conclusion of their contracted period and their wives and children were unable to enter Australia. According to Carter, there were numerous servicemen who were forcibly taken aboard ships after attempts to remain in Japan and more tragically, several couples decided to commit suicide rather than separate. ${ }^{72}$ Whilst the BCOF policy may have deterred numerous servicemen from providing support for their partners, it can be assumed that there were a number who were simply unwilling to acknowledge responsibility for their offspring. ${ }^{73}$ It is a sentiment reiterated by Carter,

...many of them had wives at home in Australia. Few regarded the marriages as binding. ${ }^{74}$

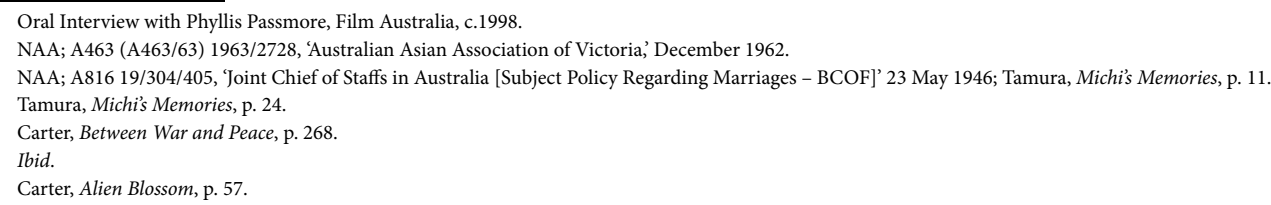


Passmore also acknowledges this common occurrence,

...well, most of them, some of them had babies and that, and Australian soldiers, well the Americans did the same, just got up and went home and left them. ${ }^{75}$

The women were essentially encumbered with the sole responsibility of the children and were forced to re-establish their lives in Japan. ${ }^{76}$

The limited acknowledgement of these women in existing literature implies that their experiences are somehow historically irrelevant but this view is entirely incorrect. The women were not only active participants in the post-war period but they also indirectly influenced the procedures of the occupation. Moreover, the women exerted agency in the decisions to become involved in relationships with the personnel. It was an agency, however, that was only available within the larger patriarchal discourse by which they were primarily disadvantaged. By demonstrating that the women do indeed possess a historically significant past, there emerges an incontrovertible necessity for the experiences of these women to be further examined. The analysis of hitherto overlooked regional newspapers will illuminate these experiences with respect to prevalent attitudes towards women involved in relationships with foreign servicemen and the construct of the feminine role.

\section{Confronting The Silence}

Neither the Chügoku Nippo nor the Chügoku Shinbun reported any fraternisation between Japanese women and Australian personnel within the defined occupation period from 1946 through to 1952 . This omission can be partially attributed to the elaborate censorship apparatus implemented under American and later Allied control. The censorship laws, fully operating for four years from September 1945 and subsequently imposed in altered forms until Japan regained its sovereignty, forbade the transmission of any information regarding criticism of Australia, prostitution and other incriminating subjects. ${ }^{77}$ Somewhat paradoxically, it is the maintenance of this rigid censorship that reveals the extent to which the BCOF authorities feared that any attention drawn to fraternisation amongst servicemen and Japanese women would compromise the disparity in power they sought to enforce.

Oral Interview with Phyllis Passmore, Film Australia, c.1998.

6 Tamura, Michi's Memories, p. 14.

77 Dower, op. cit., p. 406. 
.

The conclusion of the peace treaty in 1952 and the diminished presence of the Australian military in Kure from the following year enabled an increase in articles concerning previously prohibited and silenced subjects such as fraternisation. These articles provide the opportunity to consider the positions of those women who were actually or perceived to be involved in the prostitution industry as well as those who migrated to Australia after marrying their partners. The categorisation of these women is a revealing testament of the underlying social attitudes in this period towards those in relationships with military personnel. In other words, these articles expose the existing view that women who had not attained a marriage contract were considered as common prostitutes. Such attitudes particularly applied to the women labelled 'only ones' who lived with their foreign partners. ${ }^{78}$ It is a sentiment that is best articulated in this excerpt from Michi's Memories,

I was aware of the hostility people felt towards the women who were walking with the occupation soldiers. People did not bother to distinguish those ordinary girls from prostitutes and categorised all of us as call girls. ${ }^{79}$

There were, unquestionably, a vast number of prostitutes involved with personnel. Indeed, at a sole brothel in the city, approximately seventy percent of the clientele were estimated to be Australian servicemen. ${ }^{80}$ This does not, however, signify that all unmarried women were prostitutes but nevertheless, it is within this cohort that women who bore children to Australian personnel were most often grouped.

In the majority of the articles, the women encapsulated in this category are described in a distinctly derogatory manner. Depictions of the women clustering near the military camps and clamouring for the attention of the personnel, for example, create an image of immorality and degradation. ${ }^{81}$ This is reinforced in the publication of surveys that focus upon the youth, poverty and limited education of the women. According to an investigation conducted of approximately 1,200 'streetwalkers', for example, the predominant majority were identified as between the ages of 20 and 25 but there were also eighty-nine who were not yet eighteen. ${ }^{82}$ Similarly, a separate examination of 259 prostitutes listed only ninety-seven who had completed both elementary and secondary education. This article also asserts that the principal catalyst for entering this industry was poverty. Indeed, this examination identifies 91 women who became prostitutes as means of confronting

\footnotetext{
'Aspects of Kure, The International City - Secrecy; Kokusai toshi Kure no hyōjō - onrii ni onmitsu,' Chūgoku Nippo, 21 August 1952. Tamura, op. cit., p. 24

'These Are The Realities of Streetwalkers; Yoruno on'na no jittai wa kō', Chügoku Nippo, 15 July 1953.

'Survey on Prostitutes in Kure (1); Kure no gaishō kansatsu (1) Kanzaki Kiyoshi shi chōsa happyō,' Chūgoku Nippo, 24 December 1952; 'First Ray of Hope for Solving the Prostitution Problem in Kure; Kichi Kure füki mondai kaiketsu e shokō', Mainichi Shinbun, 27 August 1953.

82 'These Are The Realities of Streetwalkers; Yoruno on'na no jittai wa kō,' Chügoku Nippo, 15 July 1953.
} 
poor economic conditions. ${ }^{83}$ Concentration upon such aspects within the articles shows the representation of this cohort of women as both pitiful and contemptible and such attitudes were therefore circulated through the general Japanese population, if not produced by them.

Furthermore, these women were viewed as solely motivated by the desire for material necessities. In one such example describing the arrival of the BCOF, the article emphasises that there were an extensive number of prostitutes who prepared to greet the incoming force for the sole purpose of obtaining scarce luxury items. As stated in the article, 'At four or five 'o'clock, women were leaving from rooms on the warship with chocolate and tobacco. ${ }^{84}$ Such reasons understandably constituted the motivation of those working in the prostitution industry to engage in casual, sexual encounters with the servicemen but this was viewed to be the premise of all unmarried women in relationships with Australian personnel. ${ }^{85}$ It was particularly the 'only ones', who were represented as keen to profit from the disposable income of the servicemen, apparently extolling the sentiment, 'The blue-eyed army are generous with their money.86 The focus upon this as the sole motivating factor reiterates the degraded image of these women and characterises them even further as exploitative and thus, dishonourable.

The clear distinction between the two cohorts of women - those perceived to be engaged in prostitution and those married to Australian servicemen - becomes apparent in examining the articles concerning the 'war brides'. There is particular emphasis, for example, upon the legally binding union of the couples; the women are only referred to as 'brides' or in conjunction with their married partners as 'couples' or 'pairs. ${ }^{87}$ It is a sentiment that is reiterated in an article describing the marriage between Gordon Parker and Sakuramoto Nobuko. The article subjectively describes their relationship using figurative and poetic language, 'Their dear love was crystallized in the form of their eldest daughter. In contrast to the women cast as prostitutes, the article emphasises that the premise of this relationship was the mutual affection and respect the couple shared. It is also articulated in the statement, 'The two gave themselves to their love.88

The marriage of women to foreign servicemen was not, however, wholly encouraged. At least one article concentrates upon the annulment sought by a woman

\footnotetext{
'Life of Prostitutes; Baishunfu no seitai,' Chūgoku Shinbun, 6 July 1952.

4 'Survey on Prostitutes in Kure (1); Kure no gaishō kansatsu (1) Kanzaki Kiyoshi shi chōsa happyō', Chūgoku Nippo, 24 December 1952.

Tamura, 'An Ordinary Life?', Meanjin, 61, 1, March, 2002.

'Aspects of Kure, The International City - Secrecy; Kokusai toshi Kure no hyōjō - onrii ni onmitsu,' Chūgoku Nippo, 21 August 1952.

'War Brides Depart From Australia; Hanayome-san gōshū e shuppatsu,' Chūgoku Shinbun, 2 April 1953; 'Departure of 40 Intermarried Couples From

Kure on 12th March; Kokusai kekkon 40 kumi 12 nichi Kure kara funade,' Asahi Shinbun, 8 March 1953.

88 'First War Bride Arrives In Australia - Sakuramoto Nobuko From Kure; Gōshū iri hanayome dai 1 gō - Kure no Sakuramoto Nobuko san,' Chūgoku

Shinbun, 10 April 1952.
} 
.

who was unwilling to migrate to Australia to live with her husband. Whilst the article posits the decision as the woman's own, it is implied that she was prompted to pursue this action at the recommendation of her relatives and acquaintances ${ }^{89}$ Clearly, there still existed certain disapproval even for those women who entered into legal unions with their partners but such condemnation is in direct contrast to the immoral, disrespectful image of the other cohort of women described.

The only article directly addressing the women who bore children to Australian personnel portrays this cohort of women as much more closely associated to the image of those classed as prostitutes than the 'war brides'. Most demonstrably, the article centres upon a woman who committed theft to support her two children of Australian paternity. ${ }^{90}$ Such immediate focus upon the societal crime of the mother creates a patently shameful and disrespectful image not indistinct from that of prostitutes engaged in casual, sexual encounters with the servicemen. This is further reinforced in the description of the woman as a 'mistress' of an Australian soldier who had not fulfilled his promise to return to Japan. It implies that the relationship the woman engaged in was much more illicit and furtive than those formalised in marriage. Moreover, the article proposes that the sole reason the woman entered into a liaison with the serviceman was to obtain material necessities. Indeed, as rendered in the following excerpt, material desires were assumed to be the reason for all women who bore children to Australian personnel, 'The Japanese women became mistresses in admiration of the lifestyle of the occupation forces. Such depictions of the women as immoral and dishonourable are indicative of the social attitudes towards those who bore children to Australian personnel.

Besides the existence of such attitudes in the newspapers, these women were mocked and bullied in the greater Kure community. Alien Blossom provides an example of the nature of this prejudice,

Some women to whom Japanese-Australian babies had already been born were shunned and despised. People made loud remarks about them in the streets, about the "ainoko"- the mongrels born to these brazen ones. There was laughing and sniggering behind the hand or even more. ${ }^{91}$

This extract implies that it was the illegitimacy of the children that was the central premise for such antagonism but the personal memoir, Michi's Memories, alludes to a separate cause. The relief Michi expresses at the realisation that her Australian partner

\footnotetext{
89 'First Annulment of Marriage Between an Australian Soldier and a Japanese Woman; Gōgunjin to kekkon kaishō dai 1 gō', Chūgoku Shinbun, 9 December 1954.

90 'Hopeless Mother Committed Theft For Her Two Mixed-Blood Children; Aware konketsuji no hahaoya 2ji o kakaete nusumi,' Chügoku Nippo, 6 May 1952.

91 Carter, Alien Blossom, p. 72.
} 
did not abandon her and her children suggests that there was a stigma attached to those who were viewed as discarded by the personnel,

I was so relieved to know he had not abandoned us. The children did not need to grow up as fatherless kids. I could not help showing the letter to every visitor and telling them that he did not leave us behind at all. ${ }^{92}$

The limited representation of the women and the negative attitudes within the newspaper articles point to the underlying social prejudice that was an integral part of the experience of those who bore children fathered by Australian personnel.

The analysis of the experiences of these women also draws focus to the socially and culturally derived construct of the feminine role in this period. The concept of ryosai kenbo or 'good wife, wise mother' was first articulated in the aftermath of the Sino-Japanese War in 1894-1895 by prominent male figures within the Ministry of Education. Promulgated through mass media and the upper levels of both public and private schools, this construct defined the contribution of women to the Imperial state to be in their dual capacity as 'good wives and wise mothers. ${ }^{93}$ In addition to exhorting the importance of devotion to motherhood and wifehood, the construct emphasised the virtues of modesty, chastity and obedience to parents, husbands and in-laws. ${ }^{94}$

As Uno contends, ryosai kenbo did not correspond to the actual experiences of most women. ${ }^{95}$ Extensive restructuring of the state and society enacted through the imposition of democracy after 1945 further affected conceptions of womanhood, particularly those championed in this ideal. ${ }^{96}$ The association of ryosai kenbo with prewar imperial state militarism contributed further to the decline of the construct as the epitome of Japanese womanhood. ${ }^{97}$ Ryosai kenbo, however, did not immediately dissipate after 1945 and continued to influence perceived norms of the feminine role in the postwar period..$^{98}$ Certainly, the representation of the women who bore children fathered by Australian personnel within regional newspapers was largely framed by this discourse.

Most demonstrably, the women are depicted solely within their perceived roles as mothers to their children. This is exemplified in the article concerning the woman who committed theft, who is referred to only as 'mother' or 'parent.' Furthermore, the article emphasises the effect of committing such a crime upon children,

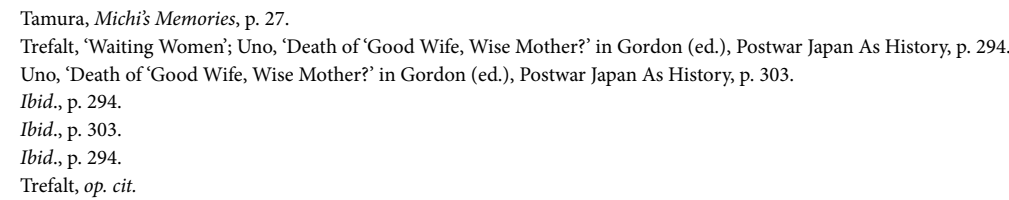


What kind of future will these children have surrounded by such things?99

Defining this cohort of women by their positions as mothers is not limited to this article, it is also apparent in those concerned with the 'mixed-blood' children. In one such example, the women are described as overanxious to ensure that their children would not be subject to bullying in school and keen to secure them a complete education. ${ }^{100}$ Such depictions cast the women as actively and positively engaged in their perceived duty as mothers but this is not the uniform image within this selection of articles.

Indeed, the majority are much more concerned with questioning the ability of the women to raise their children. One article, for example, addresses the planning of a discussion concerning the education of Japanese-Australian children,

All concerned education officers, related principals and vice principals will attend a discussion on the points at issue and actual circumstances regarding the education of mixed-blood children. ${ }^{101}$

Whilst the article states that it was an informal meeting, the required attendance of all education personnel implies that the welfare of these children was viewed as a priority in the region. In a separate article, the management of the children is described to be profoundly troubling,

The Parent Teacher Association and others have had deep concerns about how to directly handle the education of these children.

Such concern prompted a proposal to create a special education class solely for children fathered by Australian personnel despite only fourteen entering school in the entire Hiroshima region in that particular year. ${ }^{102}$ Certainly, it could be inferred that this focus upon the management of the children was considered positive and necessary for addressing issues that may have developed as a result of their mixed parentage. Concentrating upon such topics, however, also implies that the women are somewhat inadequate in their capacities as mothers.

An investigation conducted by the International Social Service of Japan in 1958 further exemplifies the way in which the construct of motherhood framed the experiences of these women. The purpose of the survey was to ascertain the socio-

\footnotetext{
99 'Hopeless Mother Committed Theft For Her Two Mixed-Blood Children; Aware konketusji no hahaoya 2ji o kakaete nusumi', Chūgoku Nippo, 6 May 1952.

100 '18 Mixed-Blood Children Enter Primary Schools- Kure Education Board Does Its Best; Konketsuji nyūgaku 18 mei, Shiyōi ga banzen o kisu', Chūgoku Nippo, 22 January 1956; 'How To Bring Up Mixed-Blood Children?; Konketsuji o dō sodateru', Chügoku Nippo, 26 June 1954.

101 'Survey of Mixed-Blood Pupils By The Ministry of Education; Konketsu gakudō jittai chōsa monbushō kara raigo', Chūgoku Nippo, 20 February 1955.

102 'How To Deal With Mixed-Blood Children?; Konketsuji o dō atsukau', Chūgoku Nippo, 27 January 1953.
} 
economic circumstances of the children, which necessarily entailed acquiring details of their parents. The women, however, are addressed only within their capacity to shelter, financially support and provide for their children. The survey, for example, indicated that eighty percent of the women and their children required some form of economic assistance. More indicatively, the investigation focused upon the occupation and income of the women. Almost one-half of the women supported themselves and their families through bar work or other comparable employment but many were clearly not engaged in work at all as monthly incomes were reported to have been between 0 and 9000 yen. ${ }^{103}$ The ability of the women to provide materially for their children is further questioned in another investigation, which emphasises that a minor number of children needed to be adopted into homes of relatives or friends. The article describes these women in a particularly derogatory manner,

Some twelve of them have been dumped by their heartless parents. ${ }^{104}$

The experiences of the women who bore children to foreign servicemen cannot be easily encompassed within the narrow parameters of the 'good wife, wise mother' ideal. This discourse, however, framed the representation of these women within regional newspapers, thus also demonstrating the continuation of this construct in the early post-war period.

\section{Conclusion}

This investigation has not only shown that the experiences of these Kure women have been largely relegated to the periphery of existing scholarship but has also sought to demonstrate that a meaningful history can be written for those excluded from conventional interpretations. As demonstrated in this article, moreover, such imposed barriers of silence can be confronted and overcome through the analysis of carefully selected material.

The women were active participants in this period who influenced the conduct of the military operation through the attraction they posed for personnel and the possibilities this created for fraternisation. The introduction of the non-fraternisation policy and the arbitrary venereal disease examinations, for example, can be largely attributed to this cohort of women. More importantly, the women did exercise a certain level of agency, particularly in their decisions to pursue relationships with servicemen. It was an agency that was limited, however, by prevailing patriarchal discourses such as the overarching

103 NAA; A1838; 3103/10/12/1 PART 1, 'Social Study of Children of Mixed Ethnic Origin in Kure City, Hiroshima-ken, Japan,' 15 September 1958. 104 'Mixed Blood Children- A Parting Present From BCOF; Eirenpōchūryūgun okimiyage no konketsuji,' Chūgoku Nippo, 22 December 1956. 
military environment and the construct of the feminine role.

This article has unearthed certain aspects of the experience for women who bore children to Australian personnel. In particular, the examination of a previously overlooked selection of local newspaper articles has illuminated the pervasive social prejudice targeted at women involved with the occupying personnel. Such attitudes attached a certain stigma to these women who were encumbered with the sole responsibility of their children. The women were not only perceived to be indistinct from common prostitutes but they were also viewed to be abandoned, single parents of illegitimate children. This investigation has also conveyed the extent to which the established ideal of Japanese womanhood framed the representation of these women in regional newspapers circulated in this period. Most significantly, the predominance of this construct meant that the ability of the women to adequately care for their children was continually questioned.

\section{References}

Baerweld, H., The Purge of Japanese Leaders under the Occupation (Berkeley: University of California Press, 1959).

Beasley, W. G., The Rise of Modern Japan: Political, Economic and Social Change Since 1850 (New York: St. Martin's Press, 2000).

Berger, S., Feldner, H., and Passmore, K., Writing History: Theory and Practice (London: Hodder Arnold, 2003).

Biddiscombe, A.., 'Dangerous Liaisons: The Anti-Fraternization Movement in the U.S. Occupation Zones of Germany and Austria, 1945-1948, Journal of Social History, 34, 3, Spring, 2001, p. 611-647.

Black, J. and MacRaild, D. M., Studying History (New York: Palgrave, 1997).

Buckley, R., Occupation Diplomacy: Britain, the United States and Japan 1945-1952 (Cambridge: Cambridge University Press, 1982).

Carr, E., What Is History? (Harmondworth: Penguin, 1964).

Carter, I., Alien Blossom: A Japanese-Australian Love Story (Melbourne: Lansdowne, 1965).

Chida, T. (ed.), Kure No Ayumi II (Kure: Kure City Office, 1996).

Chida, T., 'Japanese Research on the Occupation of Post-War Japan by British and Commonwealth Forces: New Developments and Contemporary Source Problems,' Australia-Japan Research Project, March, 1999, Available Online: http://ajrp.awm.gov.au/ajrp/ajrp2.nsf/aa9b3f3247a3c8ae4a25676300078dee/8129b8698952f1414a25 5f0500221597?OpenDocument.

Confino, A., 'Collective Memory and Cultural History: Problems of Method', American Historical Review, December, 1997, p. 1386-1403. 
Davies, G., The Occupation of Japan: The Rhetoric and the Reality of Anglo-Australasian Relations 1939-1952 (St. Lucia: University of Queensland Press, 2001).

De Matos, C., 'The Occupiers and the Occupied: A Nexus of Memories', New Voices: Cross-Cultural Encounters in the Australia-Japan Relationship, 1, The Japan Foundation, Sydney, p. 1-12.

Dennis, P. (ed.), 1945 War and Peace in the Pacific: Selected Essays (Canberra: Australian War Memorial, 1999).

Dower, J., Embracing Defeat: Japan in the Aftermath of World War II (St. Ives: Penguin Books, 2000).

Elliot, M., Occupational Hazards: A Doctor in Japan and Elsewhere (Nathan: Australians in Asia Series, Centre for the Study of Australia-Asia Relations, Griffith University, 1995).

Evans, R. and Saunders, K., 'Visibility Problems: Concepts of Gender in Australian Historical Discourse', Australian Historical Studies, 106, 1996, p. 142-153.

Finney, P., 'Still 'Marking Time'? Text, Discourse and Truth in International History', Review of International Studies, 27, 2001, p. 291-308.

Gordon, A. (ed.), Postwar Japan as History (Berkeley: University of California Press, 1993).

Green, A. and Troup, K., The Houses of History: A Critical Reader in Twentieth Century History and Theory (Manchester: Manchester University Press, 1999).

Grey, J., 'Australia and the Post-War Occupation of Japan', Journal of the Australian War Memorial, 30, April 1997.

Hodgkin, K. and Radstone, S. (eds.), Contested Pasts: The Politics of Memory (London: Routledge, 2003).

Hopkins, R. N. L., 'History of the Australian occupation in Japan', Journal of the Royal Australian Historical Society, XL (2), 1954.

Hungerford, T. A. G., A Knockabout with a Slouch Hat: An Autobiographical Collection 1942-1951 (Fremantle: Fremantle Arts Centre Press, 1990).

Hutley, F. C., ‘Our Occupation of Japan: A Memoir', Quadrant, 28, 1-2, January/February 1984, p. 19-24.

Jenkins, K., On What Is History? From Carr and Elton to Rorty and White (London and New York: Routledge, 1995).

Lake, M., 'Women, Gender and History', Australian Feminist Studies, 7, 8, Summer, 1988, p. 1-9.

Lake, M., 'Nationalist Historiography, Feminist Scholarship, and the Promise and Problems of New Transnational Histories: The Australian Case, Journal of Women's History, 19, 1, 2007, p. 180-186.

Long, G., Australia in the War of 1939-1945: The Final Campaigns (Canberra: Australian War Memorial, 1963).

Martin, E., The Allied Occupation of Japan (Westport: Greenwood Press, 1972).

Matthews, J., 'Doing Theory or Using Theory: Australian Feminist/Women's History in the 1990's', Australian Historical Studies, 106, 1996, p. 49-58.

Matthews, J., 'New Challenges For Feminist History', Paper Delivered At The Lilith Symposium, Melbourne University, 11 July 2002, p. 1-5. 
New Voices Volume 2

Moloney, B. and Uno, K. (eds.), Gendering Modern Japanese History (Cambridge: Harvard University Asia Press, 2005).

Moore, R., 'Comment: Reflections on the Occupation of Japan', The Journal of Asian Studies, 38, 4, 1979, p. 721-734.

Moore, R., 'The Occupation of Japan as History: Some Recent Research', Monumenta Nipponica, 36, 3, 1981, p. 317-328.

Muta, S., 'The Lack of an Archives Tradition in Japan: Issues Surrounding the Planned Centre for Modern Japan-Asia Relations,' Australia-Japan Research Project, March, 1999, Available Online: http://ajrp.awm.gov.au/ajrp/ ajrp2.nsf/aa9b3f3247a3c8ae4a25676300078dee/a4a9b7f42f0568434a25677f00221ac4?OpenDocument.

O’Neill, R., Australia and the Korean War (Canberra: Australian War Memorial and Australian Government Publishing Service, 1981).

Oliver, P., Allies, Enemies and Trading Partners: Records on Australia and the Japanese (Canberra: National Archives of Australia, 2004).

Passin, H., 'The Occupation - Some Reflections,' Daedelus, 119, 3, 1990, p. 107-129.

Pateman, C. and Pateman, E. (eds.), Feminist Challenges: Social and Political Theory (Sydney: Allen and Unwin, 1986).

Reischauer, E., Japan: Tradition and Transformation (Boston: Houghton Mifflin Company, 1989).

Roberts, R., 'History and Memory: The Power of Statist Narratives', The International Journal of African Historical Studies, $33,3,2000$, p. 513-522.

Russell, P., 'Empathy, Imagination and Feminist History', Lilith, 13, 2004, p. 1-11.

Scott, J. W., Gender and the Politics of History (New York: Columbia University Press, 1988).

Scott, J. W., 'The Evidence of Experience,' Critical Inquiry, 17, Summer, 1991, p. 773-797.

Sodei, R., Dear General MacArthur: Letters from the Japanese during the American Occupation (Maryland: Rowman and Littlefield Publishers, 2001).

Tamura, K., 'Kure City History Project', Australia-Japan Research Project, March, 1997. Available Online: http://ajrp. awm.gov.au/ajrp/ajrp2.nsf/437f72f8ac2c07238525661a00063aa6/150731ff0bb63b3e852565b000499e7a?Ope nDocument.

Tamura, K., Michi's Memories: The Story of a Japanese War Bride (Australian National University: Research School of Pacific and Asian Studies, 2001).

Tamura, K., 'An Ordinary Life?', Meanjin, 61, 1, March, 2002, p. 127- 133.

Torney, P., 'Renegades to Their Country: The Australian Press and the Allied Occupation of Japan 1946-1950', War and Society, 25, 1, May, 2006, p. 89-110.

Trefalt, B., 'Waiting Women: The Return of Stragglers and Japanese Constructions of Womanhood in Collective Memories of World War II, 1972-1974', Intersections: Gender, History and Culture in the Asian Context, 5, May, 2001.

Trouillet, M., Silencing The Past: Power and the Production of History (Boston: Beacon Press, 1995). 
Ward, R. and Shulman, F., The Allied Occupation of Japan 1945-1952: An Annotated Bibliography of Western-Language Materials (Chicago: American Library Association, 1974).

White, H., Tropics in Discourse: Essays in Cultural Criticism (Baltimore: The John Hopkins University Press, 1978).

Wilkinson, J., 'A Choice of Fictions: Historians, Memory, and Evidence,' PMLA, 111, 1, January, 1996, p. 80-92.

Wood, J., The Forgotten Force: The Australian Military Contribution To The Occupation of Japan 1945-1952 (St. Leonards: Allen and Unwin, 1998).

Wood, J., 'The Forgotten Force: The Australian Military Contribution to the Occupation of Japan 1945-1952', Journal of the Royal United Services Institute of Australia, 23, December 2001, p. 39-41.

\section{Dissertations}

Carter, C., Between War and Peace: The Experience of Occupation for Members of the British Commonwealth Occupation Force 1945-1952, PhD Dissertation, Australian Defence Force Academy, 2002. Available Online: http://www. library.unsw.edu.au/ thesis/adt-ADFA/public/adt-ADFA20040827.130536.

\section{Television Program Transcripts}

Kure Kids, Foreign Correspondent, ABC TV, $9^{\text {th }}$ August 2005.

\section{Archival Material}

Chūgoku Shinbun, Hiroshima

'BCOF Headquarters Set Up In Kure; Kure ni Eirenpōgen shireibu', 4 February 1946.

'Stunned Kure Citizens - Treat BCOF With Respect; Menkuratta Kure shimin - Eigōgun niwa seii o motte,' 7 February 1946.

'BCOF Soldiers Gallantly Arrived in Kure Wearing Wide-Brimmed Hats; Sassō tsubahiro bōshi de eigōgun Kure ni,' 15 February 1946.

'Main Forces of BCOF Arrived in Kure on 28 March 1946; Eishuryoku 28 nichi tōchaku', 29 March 1946.

'Kure and BCOF; Kure to shinchūgun no maki', 17 April 1949.

'Understanding of Australia Improved Through Occupation; Gō, chūhei de rikai fukamu', 30 August 1951.

'First War Bride Arrives In Australia-Sakuramoto Nobuko From Kure; Gōshū iri hanayome dai 1 gō - Kure no Sakuramoto Nobuko san', 10 April 1952.

'Life of Prostitutes; Baishunfu no seitai,' 6 July 1952.

'Marriages Between Australian Servicemen and Japanese Women To Be Permitted After Investigation; Chōsa no ue kyoka suru gō shōhei to nihonjin no kekkon', 22 June 1952.

'War Brides Depart From Australia; Hanayome-san gōshū e shuppatsu', 2 April 1953.

'First Annulment of Marriage Between an Australian Soldier and a Japanese Woman; Gōgunjin to kekkon kaishō dai 1 
New Voices Volume 2

gō', 9 December 1954.

'Eleven Mixed-Blood Children Start Primary School - Kure Education Board Prevents Discrimination; Shin nyūgaku konketsuji 11 mei Kure shi kyōi futō atsukai bōshi', 18 March 1956.

'Suggestions for Education for Mixed-Blood Children; Konketsuji kyōiku ni shisa,' 7 May 1956.

Chūgoku Nippo, Kure

'Hopeless Mother Committed Theft For Her Two Children; Aware konketsuji no hahaoya 2ji o kakaete nusumi', 6 May 1952.

'Aspects of Kure, The International City - Secrecy; Kokusai toshi Kure no hyōjō - onrii ni onmitsu', 21 August 1952.

'Survey on Prostitutes in Kure (1); Kure no gaishō kansatsu (1) Kanzaki Kiyoshi shi chōsa happyō', 24 December 1952.

'How To Deal With Mixed-Blood Children?; Konketsuji o dō atsukau', 27 January 1953.

'Where Have Mixed-Blood Children Gone?; Doko ni kieta no ka konketsuji', 19 March 1953.

‘Too Much Concern About Mixed-Blood Children; Torikoshi gurō ka konketsuji jidō', 7 May 1953.

‘These Are The Realities of Streetwalkers; Yoruno on'na no jittai wa kō', 15 July 1953.

'How To Bring Up Mixed-Blood Children?; Konketsuji o dō sodateru', 26 June 1954.

'Survey of Mixed-Blood Pupils By The Ministry of Education; Konketsu gakudō jittai chōsa monbushō kara raigo', 20 February 1955.

'18 Mixed-Blood Children Enter Primary Schools - Kure Education Board Does Its Best; Konketsuji nyūgaku 18 mei, Shiyōi ga banzen o kisu,' 22 January 1956.

'Mixed-Blood Children - A Parting Present From BCOF; Eirenpōchūryūgun okimiyage no konketsuji', 22 December 1956.

Asahi Shinbun, Japan

'Departure of 40 Intermarried Couples from Kure on 12 March; Kokusai kekkon 40 kumi 12 nichi Kure kara funade', 8 March 1953.

'Only 10\% of 129 Mixed Blood Children In Hiroshima Live With Parents; Kenka ni konketsuji 129 mei fubo to kurasuno wa 1 wari amari', 29 May 1953.

Mainichi Shinbun

'Attempts to Restrict Kure's 3,000 Prostitutes to Red Light District; Akasen chiku ni fūjikomō - me ni amaru 3,000 no on'na', 24 June 1952.

'First Ray of Hope for Solving the Prostitution Problem in Kure; Kichi Kure füki mondai kaiketsu e shokō', 27 August 1953.

National Archives of Australia

A816 19/304/405, 'Joint Chief of Staffs in Australia [Subject Policy Regarding Marriages - BCOF]' 23 May 1946. 
A6006 1949/12/31, ‘Occupation Force Policy’' 30 July 1949.

A5799/99/1949, 'Request to the Department of Defence From Lt. Gen. H.C.H. Robertson', 30 July 1949.

A445/236/17/11, 'Entry Into Australia - Children of Australian Fathers and Japanese Mothers', 2 August 1952.

A463 (A463/17) 1957/1908, ‘Children Born in Japan of Japanese Mothers and Australian Servicemen', 16 July 1957.

A463 (A463/63) 1963/2728, 'Illegitimate Children of Australian Servicemen in Japan', 27 January 1958.

A1838 3103/10/12/1 PART 1, 'Department of External Affairs', 3 September 1958.

A1838 3103/10/12/1 PART 1, 'Social Study of Children of Mixed Ethnic Origin in Kure City, Hiroshima-ken, Japan', 15 September 1958.

A1838 3103/10/12/1 PART 1, ‘Correspondence Between Department of Defence and Air', 27 January 1959.

A463 (A463/63) 1963/2728, 'Japan - Illegitimate Children of Australian Servicemen,' 18 January 1960.

A463 (A463/63) 1963/2728, 'Department of External Affairs: Inward Savingram', 29 January 1960.

A463 (A463/63) 1963/2728, 'Japan - Children of Mixed Blood', 3 February 1960.

A463 (A463/63) 1963/2728, 'House of Reps. Adjournment Debate', 29 March, 1960.

A463 (A463/63) 1963/2728, 'Press Statement by the Minister for Immigration', 30 November 1962.

A463 (A463/63) 1963/2728, 'Australian Asian Association of Victoria,' December 1962.

A463 (A463/63) 1963/2728, 'House of Representatives - Question For This Day’, 12 May 1964.

\section{Oral Interviews}

Transcripts of Oral Interviews with Sid Margetts, Mac Grant, John Coffman, Charlie Nation, Dr. Gofman, Keith Boothroyd, Dr. Dunlop, Harold Andrew, Colin East, Maurice May, Phyllis Passmore and Caroline Palmer conducted by Film Australia, c.1998 (In Private Possession of C. de Matos). 